\title{
Factors Affecting PDAM Water Demand of Household "A" Category in Purworejo Regency
}

\author{
By: \\ Zulfatus Sa'adah ${ }^{1)}$, Rusmusi Indranjoto ${ }^{2)}$, Sudjarwanto ${ }^{3)}$ \\ ${ }^{1)}$ Faculty of Economics and Business, Universitas Jenderal Soedirman \\ ${ }^{1)}$ Email: zulfatussaada@gmail.com
}

\begin{abstract}
This research aimed to analyze the effect of income, water price, number of family members, and the ownership of water source, as well as the most influential variable to PDAM demand water of household " $A$ " category in Purworejo regency Banyuurip branch. Population in this research was PDAM subscribers of household " $A$ " category in Banyuurip sub-district by 67 subscribers. The tecnique of data analysis used a multiple linear regression with Ordinary Least Square method (OLS). The analysis result indicated that water price and ownnership of other water source had a negative and significant effect, while the number of family member had positive but insignificant effect, and the income had insignificant effect to PDAM water demand of household " $A$ " category in Banyuurip sub-district.
\end{abstract}

Keywords: PDAM Water Demand, Income, Water Price, Number of Family Members, Ownership of Other Water Resources.

\begin{abstract}
ABSTRAK
Penelitian ini bertujuan untuk menganalisis pengaruh pendapatan, harga air, jumlah anggota keluarga, dan kepemilikan sumber air, serta variabel yang paling berpengaruh terhadap permintaan air PDAM rumah tangga kategori " $A$ " di Kabupaten Banyuurip Kabupaten Purworejo. Populasi dalam penelitian ini adalah pelanggan PDAM kategori " $A$ " rumah tangga di Kecamatan Banyuurip oleh 67 pelanggan. Teknik analisis data menggunakan regresi linier berganda dengan metode Ordinary Least Square (OLS). Hasil analisis menunjukkan bahwa harga air dan kepemilikan sumber air lain memiliki pengaruh negatif dan signifikan, sedangkan jumlah anggota keluarga memiliki pengaruh positif tetapi tidak signifikan, dan pendapatan memiliki pengaruh yang tidak signifikan terhadap permintaan air PDAM rumah tangga kategori " $A$ " di Banyuurip Kecamatan.
\end{abstract}

Kata Kunci: Permintaan Air PDAM, Pendapatan, Harga Air, Jumlah Anggota Keluarga, Kepemilikan Sumber Daya Air Lainnya.

\section{INTRODUCTION}

Water is the most important element in human life. It can be said that where there is water, there is a life. Human body contains $70 \%$ of water. Humans can live by not eating up to 8 weeks provided that they get enough water for their bodies. Water is used by humans for everyday needs, such as drinking, cooking, washing, and bathing. Water can bring benefits for human. For example, water is used for motorcycle and car waching business. Water is not only used for daily needs, but it is usually used for the needs of irrigation, power plants and also public purposes. Water supply is the greatest element in life. The food elements needed by human are also affected by the water component. Therefore, the need for water becomes the most important thing for the availability of water in this earth. 
Based on the calculation of World Health Organization (WHO) (2010), the water requirement for each person per day is 30 liters, 20 liters is used for sanitation and 10 liters is used for consumption. Based on the data of Central Statistics Agency, with Indonesian population of 257 million people, the water consumption for all people in Indonesia in 2014 was 7.56 billion liters. The amount of water needed by the Indonesian people will increase by 8.55 billion liters per day in the next ten years.

According to the United Nations Water Department Report, the world food demand will increase by 70 percent in 2050, causing water demand for agriculture to increase by 19 percent, while 70 percent of water has been used for the needs of agriculture in 2012. Water demand is increasing daily, the quantity is adequate for daily needs, but the quality is not necessarily adequate because every region is different. There is water suitable for consumption and the one which is not in every region. To overcome the problem, the people are looking for a source of clean water suitable for consumption. Therefore, the government provides clean water to meet the community needs through Regional Water Company (PDAM).

Regional Water Company (PDAM) is a regional company that provide services in the form of distribution of clean water sources to the community, so that people have access to clean water (Kereta, 2014). According to the regulation of the Minister of Health of the Republic of Indonesia No. 416 of 1990 on the requirements and supervision of water quality, clean water is water that can be used for daily purposes whose quality meets health requirements and can be drunk after boiled it prior to use, while drinking water is water whose quality meets health requirements and can be directly drunk without previously being boiled. The Regional Water Company is authorized by the government to manage clean water and to meet the demand for clean water by the community.

The Regional Water Company (PDAM) of Purworejo Regency has an important role in providing clean water in the community. Many people in each region are interested to become PDAM subscribers. This is because many areas do not have source of clean water or the source of clean water is far from where they live. In providing water to the community, the water provided by Purworejo Regional Water Company comes from the springs of Kalinoko, Simbarjoyo, Kedungkebo, Pangenjurutengah drilled well, and Bendung Boro I (PDAM Tirta Perwitasari of Purworejo Regency). The sources of the spring are used to irrigate in various branches of PDAM in Purworejo Regency.

The Purworejo Regional Water Company (PDAM) divides the service areas into six branches, namely Purworejo, Kutoarjo, Bener, Loano, Purwodadi, and Banyuurip Branches. Each branch of PDAM serves several villages. The following Table 1.1 shows the number of PDAM subscribers by branch in Purworejo Regency.

Table 1. Number of PDAM Subscribers by Branch in Purworejo Regency in 2011-2015

\begin{tabular}{|c|c|c|c|c|c|c|}
\hline \multirow{2}{*}{ No. } & \multirow{2}{*}{ Branch } & \multicolumn{5}{|c|}{ Year } \\
\hline & & 2011 & 2012 & 2013 & 2014 & 2015 \\
\hline 1 & Purworejo & 72,770 & 75,500 & 75,485 & 86,675 & 92,370 \\
\hline 2 & Kutoarjo & 19,550 & 20,450 & 20,450 & 23,485 & 25,805 \\
\hline 3 & Purwodadi & 9,825 & 10,405 & 10,465 & 11,805 & 11,930 \\
\hline 4 & Banyuurip & 8,630 & 8,855 & 8,855 & 8,790 & 8,900 \\
\hline 5 & Bener & 7,330 & 7,365 & 7,365 & 7,260 & 7,260 \\
\hline \multirow[t]{2}{*}{6} & Loano & 1,815 & 1,820 & 1,820 & 1,820 & 1,820 \\
\hline & Total & 119,920 & 124,395 & 124,440 & 139,835 & 148,085 \\
\hline
\end{tabular}

Table 1 shows the number of PDAM subscribers by branch in Purworejo Regency from 2011 to 2015. In those years, the number of PDAM subscribers in Purworejo Regency has increased. The three regions with the largest number of subscribers are in Purworejo, Kutoarjo and Purwodadi Branches, where subscribers to those branches have increased from 2011 to 2015, while the regions with fewer subscribers were in Loano branch where the number of subscribers was relatively 
constant. From Table 1, it can be concluded that the number of PDAM subscribers have increased, so that many people need water to meet their daily needs. The largest number of subscribers using PDAM water is in Purworejo Branch, which is the center of the city.

The Regional Water Company (PDAM) of Purworejo Regency divides the non-commercial categories into household $A$, household $B$, household $C$, and government institution categories. Household A category is a low income household. Household B category is a moderate income household. While household $\mathrm{C}$ category is a high income household. The following table 2 shows the number of subscribers for non-commercial categories.

Table 2. Number of Subscribers for Each Non-Commercial Category in Banyuurip Branch in 2011-2015

\begin{tabular}{|c|c|c|c|c|c|c|}
\hline \multirow{2}{*}{ No. } & \multirow{2}{*}{ Category } & \multicolumn{5}{|c|}{ Year } \\
\hline & & 2011 & 2012 & 2013 & 2014 & 2015 \\
\hline 1 & Household A & 621 & 180 & 123 & 73 & 73 \\
\hline 2 & Household B & 541 & 958 & 1,007 & 1,053 & 1,052 \\
\hline 3 & Household C & 16 & 44 & 51 & 51 & 50 \\
\hline 4 & Institution & 18 & 19 & 21 & 21 & 22 \\
\hline & Total & 1,196 & 1,201 & 1,202 & 1,198 & 1,197 \\
\hline
\end{tabular}

Based on Table 2, it shows that the number of subscribers for each non-commercial category in Banyuurip branch in 2011 to 2015 has decreased. The household "A" category has decreased significantly from 2011 to 2015.

The Regional Water Company (PDAM) of Banyuurip Branch serves water demand to various kelurahan (urban villages) and villages in Banyuurip Sub-District. Banyuurip Sub-District serves water demand in 15 villages. Table 3 shows the villages using PDAM in Banyuurip Branch. The three regions with the largest number of subscribers using PDAM are in Banyuurip Branch, namely Boro Kulon, Sumbersari Villages and Kelurahan Kledung Karangdalem, while the three villages with the least number of subscribers using PDAM water are Tegalkuning, Sokowetan, and Wangunrejo villages.

Table 3. Villages Using PDAM Water of Banyuurip Branch in 2015

\begin{tabular}{clc}
\hline No. & Village & Number of Subscribers \\
\hline 1 & Boro Kulon Village & 899 \\
2 & Sumbersari Village & 464 \\
3 & Kelurahan Kledung & 259 \\
& Karangdalem & 191 \\
4 & Popongan Village & 170 \\
5 & Banyuurip Village & 163 \\
6 & Kelurahan Kledung & 163 \\
7 & Kradenan & 161 \\
8 & Candingasinan Village & 107 \\
9 & Condongsari Village & 96 \\
10 & Boro Wetan Village & 78 \\
11 & Pakisrejo Village & 59 \\
12 & Candisari Village & 45 \\
13 & Cengkawakrejo Village & 37 \\
14 & Tegalkuning Village & 20 \\
15 & Sokowetan Village & 8 \\
16 & Wangunrejo Village & 2.930 \\
\hline & Total &
\end{tabular}

Source: PDAM in Purworejo Regency, 2015 
Based on Table 3, the subscribers using PDAM water of Banyuurip Branch located in Banyuurip Sub-District of household A category are only 7 villages.

Table 4. Number of Subscribers by Household a Category in Banyuurip Branch

\begin{tabular}{clc}
\hline No. & Village & Amount \\
\hline 1 & Sumbersari Village & 30 \\
2 & Candingasinan Village & 14 \\
3 & Tegalrejo Village & 10 \\
4 & Condongsari Village & 8 \\
5 & Pakisrejo Village & 8 \\
6 & Tegalkuning Village & 2 \\
7 & Banyuurip Village & 1 \\
\hline & Total & 73
\end{tabular}

Source: PDAM of Banyuurip Branch, Purworejo, 2015

Table 4 shows the number of subscribers of household " $A$ " category in Banyuurip Branch. The largest number of subscribers is in Sumbersari and Candingasinan Villages, while the least number of subscribers is in Banyuurip Village.

Based on the above background description, the basis of this research is the decline in the number of subscribers in household A category in Banyuurip Branch Purworejo Regency. Therefore, this research needs to be conducted.

Based on the background description referring to Table 1.2 shows that the subscribers of PDAM of Purworejo Regency of Banyuurip Branch of household "A" category from 2011 to 2015 experienced a significant decrease. Water demand for household consumption always increases every day (Tomaso and Jacobs, 2017). Everyone needs water for drinking, washing, cooking, and bathing, even many people use water for business activities, in order to increase their income. However, the number of subscribers of household " $A$ " category has decreased.

Based on this problem, it is formulated research questions as follows:

(1) Do income, water price, number of family members, and the ownership of other water sources affect on the PDAM water demand of Purworejo Regency of Banyuurip Branch in Banyuurip Sub-District?

(2) Which variable is the most influential on the PDAM water demand of Purworejo Regency of Banyuurip Branch in Banyuurip Sub-District?

\section{ANALYTICAL METHOD}

This research was conducted in Banyuurip sub-district. This area was selected as the research location because Banyuurip is a sub-district where the number of PDAM subscribers by household " $A$ " category decreased every year. The types of data used in this research are primary and secondary data. The population in this research were 67 subscribers. The analysis technique was used to determine the effect of income (X1), water price (X2), number of family members (X3), and ownership of other water source (X4) on PDAM water demand. Data analysis method used Multiple Linear Regression method with Ordinary Least Square (OLS).

\section{RESULT}

Model

From the estimation result, it is obtained the following equation result:

$$
\wedge Y=345,089-1,502 \ln X_{1}-40,154 \ln X_{2}+0,995 X_{3}-11,100 D_{1}
$$


The constant value is 345,089 stating that if the independent variables of income, water price, number of family members and ownership of other water source are assumed zero, then the dependent variable of water demand is 345.089 .

(1) Income variable $\left(X_{1}\right)$, the value of regression coefficient of income variable is -1.502 , meaning that income variable has a negative effect on water demand. This means that if the income increases by one percent, then it will reduce PDAM water demand by 1.502 percent.

(2) Water Price Variable $\left(X_{2}\right)$, the value of regression coefficient of water price variable is 40.154, meaning that water price variable has a negative effect on water demand. This means that if the water price increases by one percent, then it will reduce PDAM water demand by 40.154 percent.

(3) Number of Family Members Variable (X3), the value of regression coefficient of number of family members variable is 0.995 , meaning that number of family members variable has a positive effect on water demand. This means that if the number of family members increases by one person, then it will increase PDAM water demand by 0.995 percent.

(4) Ownership of Other Water Source Variable $\left(D_{1}\right)$, the value of regression coefficient of other water source variable is -11.100 , meaning that ownership of other water source variable has a negative effect on water demand. This means that if ownership of other water source has 1 dummy, then it will reduce PDAM water demand by 11.100 percent.

\section{Classical Assumption Test}

Classical assumption test uses an unbiased estimation tool, if it meets the requirements of Best Linier Unbiased Estimator (BLUE). In this research, it is used normality test, multicolinearity test, heteroscedasticity test, and autocorrelation.

(1) Normality Test; To test normality, it is performed histogram analysis of normality test, the result of normality test indicates the probability value of 0.755 or greater than its alpha value $(\alpha=0.05)$, so that the distribution of research variable data is normal.

(2) Multicolinearity Test; The result of multicolinearity test indicates that the variables of income, water price, number of family members, and other water source generate Auxiliary value $\leq R^{2}$ value model. Thus, it can be determined that based on the result of client test above, there is no multicolinearity.

(3) Heteroscedasticity Test; Heteroscedasticity test using Breusch-Pagan-Godfrey test shows that the chi-square probability value is 0.062 . Based on the criteria that chi-square probability value is greater than the significance level $(\alpha=0.05)$, then the test above indicates that there is no heteroscedasticity.

(4) Autocorrelation test; To detect whether there is autocorrelation problem or not, it is used Durbin Watson test. The decision making in this analysis uses two auxiliary values obtained from Durbin Watson table, namely $\mathrm{dL}$ and $\mathrm{dU}, \mathrm{K}$ is the number of independent variables, and $\mathrm{n}$ is the number of samples. With alpha level of 5 percent, and autocorrelation test with $\mathrm{n}$ of 67 and $\mathrm{k}$ of 4 , it is obtained dL value of 1.480 and $\mathrm{dU}$ of 1.732 .

$$
\begin{aligned}
& 4-\mathrm{dL}=4-1,480=2,520 \\
& 4-\mathrm{dU}=4-1,732=2,268
\end{aligned}
$$

The Durbin Watson test indicates that there is no positive and negative autocorrelation because DW value lies between dU and 4-dU.

\section{Coefficient of Determination Test $\left(\mathbf{R}^{2}{ }_{\text {adj }}\right)$}

Coefficient of determination ( $\left.R^{2} a d j\right)$ value of 0.822 indicates that the independent variables are able to explain the percentage of 82.2 percent, while 17.8 percent is explained other variables not included in the estimation model, such as age, yard area, and season. 


\section{Simultaneous Test (F Test)}

The $\mathrm{F}_{\text {-count }}$ value is greater than $\mathrm{F}_{\text {-table }}(71.887>2.520)$, meaning that $\mathrm{H}_{1}$ is accepted and $\mathrm{H}_{0}$ is rejected. This means that the variables of income, water price, number of family members, and ownership of other water source simultaneously have a significant effect on water demand, so that the first hypothesis stating that income, water price, number of family members, and ownership of other water source simultaneously have a significant effect on the PDAM water demand by household A category in Banyuurip Sub-District is accepted.

\section{Partial Test (t Test)}

From the analysis result by using error rate of $(\alpha)=0.05$, it can be determined t-table value of 2.000 . From $t$-table value, it can be explained the effect of each independent variable on dependent variable as follows:

(1) Income Variable $\left(\mathrm{X}_{1}\right)$; T-count value of income variable of -1.382 is greater than $t$-table of -2.000 , so that $\mathrm{H}_{0}$ is accepted and $\mathrm{H}_{1}$ is rejected. This means that the hypothesis stating that income variable partially has a significant effect on PDAM water demand by household A category in Banyuurip Sub-District is rejected.

(2) Water Price Variable $\left(\mathrm{X}_{2}\right)$; $\mathrm{T}$-count value of water price variable of -3.626 is smaller than $\mathrm{t}$-table of -2.000 , so that $H_{0}$ is rejected and $H_{1}$ is accepted. This means that the hypothesis stating that water price variable partially has a significant effect on PDAM water demand by household $A$ category in Banyuurip Sub-District is accepted.

(3) Number of Family Members Variable $\left(\mathrm{X}_{3}\right) ; \mathrm{T}$-count value of number of family members variable of 1.822 is smaller than $t$-table of 2.000 , so that $H_{0}$ is accepted and $H_{1}$ is rejected. This means that the hypothesis stating that number of family members variable partially has a significant effect on PDAM water demand by household A category in Banyuurip Sub-District is rejected.

(4) Ownership of Other Water Source Variable $\left(\mathrm{X}_{4}\right)$; $T$-count value of ownership of other water source variable of -12.363 is smaller than $t$-table of -2.000 , so that $H_{0}$ is rejected and $H_{1}$ is accepted. This means that the hypothesis stating that ownership of other water source variable partially has a significant effect on PDAM water demand by household A category in Banyuurip Sub-District is accepted.

\section{Elasticity Test}

The following is the calculation of elasticity value in each variable:

Elasticity of income
Elasticity of water price

Elasticity of number of family members

$$
\begin{aligned}
& =-1,502 \times \frac{1}{18,029}=-0,083 \\
& =-40,154 \times \frac{1}{18,029}=-2,227
\end{aligned}
$$

$$
=0,995 \times \frac{3,985}{18,029}=0,220
$$

Based on the result of elasticity analysis in each variable, it can be seen that the elasticity of number of family members has the greatest value compared to other variables, so that number of family members variable is the most influential variable on PDAM water demand of household " $A$ " category in Banyuurip Sub-District.

\section{DISCUSSION}

\section{The Effect of Income on PDAM Water Demand of Household A Category in Banyuurip Sub-District} Income variable has a negative and insignificant effect on PDAM water demand of household A category in Banyuurip Sub-District. This finding is inconsistent with the findings of Iwan et al (2008), Nugroho (2008), and Zohari \& Deri (2014) that income has a positive and significant effect on water demand. This is because 47.76 percent of subscribers have the ownership of other water source, so 
that when there is an increasing income, the people do not increase the water consumption of PDAM, but they maximize the use of other water source. But in fact, 62.68 percent have an income between IDR 500,000 to 991,000 . In addition, 19 subscribers have an income between IDR 991,000 to $1,482,000$. In other words, the income is still below the Minimum Regional Wage (UMR) of Purworejo Regency of IDR 1,445,000. Thus, the subscribers can be said as poor or low income PDAM subscribers.

The Effect of Water Price on PDAM Water Demand of Household A Category in Banyuurip SubDistrict. Water price variable indicates a negative and significant effect on PDAM water demand of household A category in Banyuurip sub-district. This finding is consistent with Iwan, et al (2008) and Iklima \& Heru (2014) suggesting that water price has a negative and significant effect on water demand. This is consistent with the law of demand stating that if the price increases, then the demand will decrease. The research result indicates that if the water price increases, then PDAM subscribers of household A category will save water in supporting daily needs and maximize the use of its water source.

\section{The Effect of Number of Family Members on PDAM Water Demand of Household A Category in Banyuurip Sub-District}

Number of family members variable has a positive and insignificant effect on PDAM water demand of household A category in Banyuurip sub-district. This is inconsistent with the findings of Tamaso \& Jacob (2017), Saputra (2017), Amrullah et al. (2017), Sutama and Ikbal (2017), Ay (2008), Badriyah (2016), and Zohari \& Deri (2014) in their researches that the number of family members has a positive and significant effect on water demand. The number of family members in a household can reflect the use of water because all family members use water in daily life. The increasing number of family members will increase the expenditure to pay PDAM water.

\section{The Effect of Other Water Sources on PDAM Water Demand of Household A Category in Banyuurip Sub-District}

Other water source variable has a negative and significant effect on PDAM water demand of household A category in Banyuurip sub-district. This finding is consistent with Iwan, et al (2008), Badriyah (2016), Ay (2008), Amrullah et al. (2017), Tamaso \& Jacob (2017), and Sutama and Ikbal (2017),, suggesting that other water source has a negative and significant effect on water demand. The result indicates that from 67 PDAM subscribers of household A category, 32 subscribers have other water source. The water source is used to support daily needs and reduce water usage of PDAM, so that the cost incurred per month is lower.

\section{The Most Influential Variable on PDAM Water Demand of Household A Category in Banyuurip Sub- District}

Based on the elasticity test, the number of family members variable has the greatest value compared to other variables, which is 0.220 . This indicates that the number of family members is inelastic, meaning that the change in the number of family members has a considerable effect on PDAM water demand. This is consistent with AY (2008) and Saputra (2017) indicating that the number of family members is the most influential variable, since the number of family members reflects the amount of water usage of PDAM. The more family members, the more its usage.

\section{CONCLUSION}

Based on the discussion of research results that have been explained above, it can be concluded that the results of this research are as follows:

(1) The income, water price, number of family members, and other water source variables simultaneously have a significant effect on PDAM water demand of household A category in Banyuurip sub-district. Meanwhile, water price and ownership of other water source variables partially have a negative and significant effect on PDAM water demand, income 
variable has a negative and insignificant effect, while number of family members variable has a positive and insignificant effect.

(2) The most influential variable on PDAM water demand of household A category in Banyuurip sub-district is the number of family members.

Based on the conclusion, the implications of this research are as follows:

(1) This research finds that water price affects PDAM water demand, so that the local government should provide the lowest possible price because most of PDAM subscribers have low income or below the Minimum Regional Wage (UMR) of Purworejo Regency, so that the community is not burdened with the water price and the PDAM must improve the quality of service, so that people will still use PDAM despite the increase in water price.

(2) Ownership of other water source affects water demand, so that in order to reduce the dependence of the community on PDAM water, the community needs to make a well in supporting daily life. By utilizing home yard to make a well, the dependence on PDAM water will decrease and it can save the cost in using water.

(3) The number of family members affects water demand, so that the government needs to empower Family Planning Program "Two Children are Enough" to suppress population growth. By controlling the population, the burden of financing the number of family members will be reduced, especially in the use of PDAM.

\section{REFERENCES}

Amrullaah, R., Hasid, Z., and Noor, A. (2017). Analysis of clean water demand. Journal of Mulawarman Economics, 2(3).

Ay, B. (2008). Factors affecting the demand for clean water from the community against regional drinking water companies in Karanganyar Regency. Journal of Paradigm, 5(2), 77-93.

Badriyah, N. (2016). Analysis of factors affecting the level of PDAM water consumption against household and non-household sector customers in Lamongan City. Management Science Research, 1(1), 78-89.

Kereta, LB. (2014) Analysis of the effect of service quality on customer satisfaction in Regional Water Supply Companies (PDAMs) in East Flores Regency. Journal of Public Administration and Bureaucracy, 1(3), 96-116.

Nugroho, I.E. (2008). Analysis of clean water demand in the City of Bengkulu. Management, Accounting, and Business, 6(1), 278-284.

Saputra, Y.A. (2017). Pekanbaru City clean water demand: Case study on PDAM Tirta Salak. JOM Fekom, 4(1), 1-13.

Sutama, I.N. and Ikbal, M. (2017). Factors affecting demand for clean water in PDAM of Sumbawa City in 2017. Journal of Economics and Business, 14(1), 26-41.

Tomasoa, S.K. and Jacobs, S.L. (2017). Analysis of factors affecting the level of clean water consumption of PDAM in Ambon City. Journal of Executive, 14(1), 160-182.

World Health Organization (WHO). (2010). 